\title{
Comparative Assessment of Inflammatory Reaction in Experimental Animals after Pleurodesis with Solutions of Hydrogen Peroxide and Talc
}

\author{
Mikhail S. Izyumov; Viktor V. Bulynin, PhD; Evgeniy S. Ovsyannikov, PhD, ScD; \\ Andrey M. Bobrovskikh, PhD; Anastasia V. Medvedeva, PhD; Olga G. Deryaeva, PhD \\ Voronezh State Medical University named after N. N. Burdenko \\ Voronezh, the Russian Federation
}

\begin{abstract}
The aim of our research was to compare the nature and severity of the inflammatory process in the lungs, in the leaves of the visceral and parietal pleura, and in the adjacent subpleural tissues of the chest wall in experimental animals after pleurodesis with solutions of $3 \%$ and $6 \%$ hydrogen peroxide, and talc.

Methods and Results: The experiment was carried out on 200 Wistar rats, weighing 160-180 grams, 10 specimens in a subgroup, depending on the time of the experiment, i.e. 50 specimens in each study group, including the control group. The main criterion by which we determined the comparative characteristics of the effectiveness of talc and $3 \%$ and $6 \%$ solutions of hydrogen peroxide as preparations used for chemical pleurodesis in the rats was a morphological characteristic of inflammation. This criterion was confirmed by counting free cell populations in lung tissue (lymphocytes, macrophages, neutrophils, histiocytes). All comparison groups were characterized by a gradual increase in the number of lymphocytes, macrophages and histiocytes, ranging from minimum to maximum values, and by a gradual decrease in the number of neutrophils, starting with max and ending with minimum values. The number of lymphocytes, macrophages and histiocytes were increasing faster. But at the same time, for the most part, their number was lower after pleurodesis with $6 \%$ hydrogen peroxide. The minimum number of neutrophils and the fastest possible reduction in all cases was observed in pleurodesis with $6 \%$ hydrogen peroxide.

Conclusion: Pleurodesis with a $6 \%$ solution of hydrogen peroxide as a chemical agent significantly affects the quality of the inflammatory response, reducing its duration and severity in the organs and tissues of the rats' chests, compared with a solution of $3 \%$ hydrogen peroxide and talc. (International Journal of Biomedicine. 2021;11(3):291-295.)
\end{abstract}

Key Words: pneumothorax $\bullet$ pleurodesis $\bullet$ talc $\bullet$ hydrogen peroxide $\bullet$ free cell populations

For citation: Izyumov MS, Bulynin VV, Ovsyannikov ES, Bobrovskikh AM, Medvedeva AV, Deryaeva OG. Comparative Assessment of Inflammatory Reaction in Experimental Animals after Pleurodesis with Solutions of Hydrogen Peroxide and Talc. International Journal of Biomedicine. 2021;11(3):291-295. doi:10.21103/Article11(3)_OA7.

\section{Introduction}

According to the latest data, spontaneous pneumothorax (SP) has been identified in $6.2 \%-7.1 \%$ of patients with nonspecific lung diseases. This pathology tends to increase steadily, and currently there are about 15 patients per 100,000

*Corresponding author: Evgeniy $S$. Ovsyannikov, PhD, ScD. Department of faculty therapy, Voronezh State Medical University named after N.N. Burdenko.Voronezh, Russia. E-mail: ovses@ yandex.ru inhabitants per year. It is important to note that the prevalence of SP is 7.4-18 cases per 100,000 men and 1.2-6 cases per 100,000 women per year. According to the results of several studies, ${ }^{(1)} \mathrm{SP}$ accounts for $11.2 \%$ of all acute pathology faced by thoracic surgeons. Note that this pathology is often found among people suffering from chronic obstructive pulmonary disease (COPD) - 26 cases per 100,000 population per year. ${ }^{(2)}$ According to modern conceptions, the cause of nonspecific SP in $94.5 \%$ of cases is the destruction of emphysematous altered bulls, thereby once again confirming that $\mathrm{SP}$ is a complication of pulmonary emphysema and COPD. . $1,3-5)^{-5}$ 
The question of preventing the recurrence of SP remains relevant. A significant number of authors consider it necessary to use chemical pleurodesis in cases of pneumothorax occurrence, and even more in cases of its recurrence. Currently, various chemical agents are used for chemical pleurodesis: talc, olive oil, 40\% glucose solution, hypertonic sodium chloride solution, acromycin, 96\% alcohol solution and many others. ${ }^{(1,6-8)}$

An important and common drawback of the chemical agents used is the development of an excessive inflammatory response with severe pain and the development of various complications in the future.

Questions persist: What is the optimal chemical agent to perform pleurodesis? Taking the above data into consideration, we can claim that this scientific study is relevant.

The aim of our research was to compare the nature and severity of the inflammatory process in the lungs, in the leaves of the visceral and parietal pleura, and in the adjacent subpleural tissues of the chest wall in experimental animals after pleurodesis with solutions of $3 \%$ and $6 \%$ hydrogen peroxide, and talc.

\section{Materials and Methods}

The experiment was carried out on 200 Wistar rats, weighing 160-180 grams, 10 specimens in a subgroup, depending on the time of the experiment, i.e. 50 specimens in each study group, including the control group.

SP was simulated in rats under ether anesthesia by injection of air in the volume of $2 \mathrm{ml}$ through a Velish needle.

After 1 hour under ether anesthesia, one of the chemical agents with a volume of $1.0 \mathrm{ml}$ (hydrogen peroxide solution at concentrations of $6 \%$ or $3 \%$, talc) was sprayed with a Velish needle and the air from the pleural cavity was removed. Then the animals were observed and killed in groups on Days 3, 5, 7, and 30 of the experiment. In vivo experiments were carried out in accordance with the legislation of the Russian Federation, in strict compliance with the European Convention for the protection of animals used for experimental and other purposes (Strasbourg, France, 1986), the provisions of Directive 210/63/EU of the European Parliament and the Council of the European Union of 22 September 2010 on the protection of animals used for scientific purposes (Article 27).

At opening of pleural cavities of the experimental animals, organs and tissues of the thorax were sampled for histological research. Pieces of lungs with adjacent parts of the chest wall were fixed in $10 \%$ neutral formalin and stained using standard histological techniques. Paraffin sections 6-7 microns thick after de-embedding (removing of paraffin) were stained with H\&E for review.

In histological examination, we performed a comparative analysis of the severity of inflammatory changes in the interstitium of the lungs and commissure formation, depending on the agent used in pleurodesis.

The main criterion by which we determined the comparative characteristics of the effectiveness of talc and $3 \%$ and $6 \%$ solutions of hydrogen peroxide as preparations used for chemical pleurodesis in the rats was a morphological characteristic of inflammation. This criterion was confirmed by counting free cell populations in lung tissue (lymphocytes, macrophages, neutrophils, histiocytes).

Statistical analysis was performed using Microsoft Excel software package. For descriptive analysis, results are presented as median (Me), first quartile (25th percentile) and third quartile (75th percentile)._A non-parametric Kruskal-Wallis test was used for comparisons of median values among groups.

\section{Results}

The results of descriptive statistics for free cell elements in tissues after chemical pleurodesis are presented in Table 1. The distribution of the compared values in most samples was abnormal.

The data in Table 2 indicate that the method of pleurodesis significantly affects the number of free cell elements. The differences between all pairs were estimated by the Kruskal-Walliss criterion as significant, as the significance levels were $<0.05$.

On Day 3 after pleurodesis with 6\% hydrogen peroxide, the number of lymphocytes was less than after 3\% hydrogen peroxide by $13.33 \%$ and after talc by $33.33 \%$, but more than in the control group by $13.33 \%$. The number of macrophages was greater than after $3 \%$ hydrogen peroxide by $8.33 \%$, less than after talc by $25 \%$, and more than in the control group by $25 \%$. The number of neutrophils was less than after $3 \%$ hydrogen peroxide by $21.15 \%$ and after talc by $25 \%$, but more than in the control group by $48 \%$. The number of histiocytes on Day 3 after pleurodesis with $6 \%$ hydrogen peroxide was less than after $3 \%$ hydrogen peroxide by $8.33 \%$ and after talc by $16.66 \%$, but more than in the control group by $8.33 \%$.

On Day 5 after pleurodesis with 6\% hydrogen peroxide, the number of lymphocytes was less than after $3 \%$ hydrogen peroxide by $8.33 \%$ and after talc by $20.83 \%$, but more than in the control group by $45.83 \%$. The number of macrophages was greater than after $3 \%$ hydrogen peroxide by $20.0 \%$, less than after talc by $6.66 \%$, and more than in the control group by $46.66 \%$. The number of neutrophils was less than after $3 \%$ hydrogen peroxide by $27.5 \%$ and after talc by $37.5 \%$, but more than in the control group by $25 \%$. The number of histiocytes on Day 5 after pleurodesis with $6 \%$ hydrogen peroxide was less than after $3 \%$ hydrogen peroxide by $18.18 \%$ and after talc by $27.77 \%$, but more than in the control group by $36.36 \%$.

On Day 7 after pleurodesis with 6\% hydrogen peroxide, the number of lymphocytes was more than after $3 \%$ hydrogen peroxide by $11.53 \%$ and after talc by $3.85 \%$ and more than in the control group by $73.5 \%$. The number of macrophages was greater than after 3\% hydrogen peroxide by $6.25 \%$, less than after talc by $12.5 \%$, and more than in the control group by $43.75 \%$. The number of neutrophils was less than after $3 \%$ hydrogen peroxide by $33.3 \%$ and after talc by $42.2 \%$, but more than in the control group by $15.5 \%$. The number of histiocytes on Day 7 after pleurodesis with $6 \%$ hydrogen peroxide was less than after $3 \%$ hydrogen peroxide by $18.18 \%$ and after talc by $36.36 \%$, but more than in the control group by $63.63 \%$. 
On Day 10 after pleurodesis with 6\% hydrogen peroxide, the number of lymphocytes was more than after $3 \%$ hydrogen peroxide by $8.95 \%$, less than after talc by $8.95 \%$ and more than in the control group by $68 . .65 \%$. The number of macrophages was greater than after $3 \%$ hydrogen peroxide by $10.52 \%$, less than after talc by $15.78 \%$, and more than in the control group by $52.63 \%$. The number of neutrophils was less than after 3\% hydrogen peroxide by $19.23 \%$ and after talc by $30.76 \%$, but more than in the control group by $11.53 \%$. The number of histiocytes on Day 10 after pleurodesis with $6 \%$ hydrogen peroxide was less than after $3 \%$ hydrogen peroxide by $13.33 \%$ and after talc by $26.66 \%$, but more than in the control group by $46.66 \%$.
On Day 30 after pleurodesis with 6\% hydrogen peroxide, the number of lymphocytes was less than after $3 \%$ hydrogen peroxide by $6 \%$, after talc by $28 \%$, and by $58 \%$ more than in the control group. The number of macrophages was greater than after 3\% hydrogen peroxide by $9.09 \%$, less than after talc by $13.63 \%$, and more than in the control group by $59.09 \%$. The number of neutrophils was less than after $3 \%$ hydrogen peroxide by $16.66 \%$ and after talc by $29.16 \%$, but more than in the control group by $8.33 \%$. The number of histiocytes on Day 10 after pleurodesis with $6 \%$ hydrogen peroxide was less than after $3 \%$ hydrogen peroxide, on average, by $11.11 \%$ and after talc by $22.22 \%$, but by $61.11 \%$ more than in the control group.

Table 1.

Descriptive statistics for free cell elements in tissues after chemical pleurodesis

\begin{tabular}{|c|c|c|c|c|c|c|c|c|c|c|c|c|c|}
\hline \multirow{2}{*}{ Days } & \multirow{2}{*}{ Parameter } & \multicolumn{3}{|c|}{ Talc } & \multicolumn{3}{|c|}{$3 \%$ hydrogen peroxide } & \multicolumn{3}{|c|}{$6 \%$ hydrogen peroxide } & \multicolumn{3}{|c|}{ Control group } \\
\hline & & $\mathrm{Me}$ & 25 & 75 & $\mathrm{Me}$ & 25 & 75 & $\mathrm{Me}$ & 25 & 75 & $\mathrm{Me}$ & 25 & 75 \\
\hline \multirow[t]{4}{*}{3} & lymphocytes & 15 & 14 & 15 & 12 & 12 & 12 & 10 & 9 & 10 & 8 & 7 & 8 \\
\hline & macrophages & 12 & 11 & 13 & 8 & 8 & 9 & 9 & 9 & 10 & 6 & 6 & 7 \\
\hline & neutrophils & 52 & 52 & 53 & 50 & 49 & 50 & 39 & 39 & 40 & 14 & 14 & 14 \\
\hline & histiocytes & 10 & 9 & 10 & 8 & 7 & 8 & 6 & 7 & 8 & 4 & 3 & 4 \\
\hline \multirow[t]{4}{*}{5} & lymphocytes & 24 & 23 & 24 & 21 & 20 & 21 & 19 & 18 & 19 & 8 & 8 & 9 \\
\hline & macrophages & 15 & 14 & 15 & 11 & 10 & 11 & 14 & 13 & 14 & 6,5 & 6 & 7 \\
\hline & neutrophils & 40 & 40 & 40 & 37.5 & 37 & 38 & 25 & 25 & 26 & 15 & 15 & 15 \\
\hline & histiocytes & 11 & 11 & 13 & 10 & 9 & 10 & 8 & 7 & 8 & 4 & 4 & 4 \\
\hline \multirow[t]{4}{*}{7} & lymphocytes & 25 & 25 & 26 & 23 & 22 & 23 & 26 & 26 & 27 & 7 & 7 & 7 \\
\hline & macrophages & 16 & 16 & 17 & 13 & 13 & 13 & 14 & 14 & 14 & 7 & 7 & 7 \\
\hline & neutrophils & 33 & 33 & 34 & 30 & 30 & 30 & 19 & 18 & 19 & 14 & 13 & 14 \\
\hline & histiocytes & 14 & 14 & 14 & 12 & 11 & 12 & 10 & 10 & 10 & 3 & 3 & 3 \\
\hline \multirow[t]{4}{*}{10} & lymphocytes & 33.5 & 33 & 34 & 28 & 27 & 28 & 31 & 31 & 31 & 8 & 7 & 8 \\
\hline & macrophages & 19 & 19 & 19 & 13.5 & 13 & 14 & 16 & 16 & 16 & 6 & 6 & 6 \\
\hline & neutrophils & 26 & 33 & 34 & 22.5 & 22 & 23 & 18 & 18 & 18 & 15 & 15 & 15 \\
\hline & histiocytes & 15 & 15 & 16 & 13 & 13 & 14 & 11 & 11 & 12 & 4 & 4 & 5 \\
\hline \multirow[t]{4}{*}{30} & lymphocytes & 50 & 50 & 51 & 39 & 38 & 39 & 36 & 36 & 37 & 7 & 7 & 8 \\
\hline & macrophages & 22 & 21 & 22 & 17 & 16 & 17 & 19 & 18 & 19 & 6 & 6 & 7 \\
\hline & neutrophils & 24 & 24 & 24 & 21 & 21 & 21 & 17 & 16 & 17 & 15 & 15 & 15 \\
\hline & histiocytes & 18 & 17 & 18 & 16 & 16 & 16 & 14 & 13 & 14 & 3 & 2 & 3 \\
\hline
\end{tabular}


Table 2.

The results of data processing by Kruskal-Walliss criterion (P-level)

\begin{tabular}{|c|c|c|c|c|c|c|c|c|c|c|c|c|c|c|c|c|c|c|c|c|}
\hline \multirow{2}{*}{$\begin{array}{l}\text { Comparison } \\
\text { groups }\end{array}$} & \multicolumn{5}{|c|}{ Lymphocytes } & \multicolumn{5}{|c|}{ Macrophages } & \multicolumn{5}{|c|}{ Neutrophils } & \multicolumn{5}{|c|}{ Histiocytes } \\
\hline & Day & $\begin{array}{l}\text { Day } \\
5\end{array}$ & $\begin{array}{l}\text { Day } \\
7\end{array}$ & $\begin{array}{l}\text { Day } \\
10\end{array}$ & $\begin{array}{l}\text { Day } \\
30\end{array}$ & $\begin{array}{l}\text { Day } \\
3\end{array}$ & $\begin{array}{l}\text { Day } \\
5\end{array}$ & $\begin{array}{l}\text { Day } \\
7\end{array}$ & $\begin{array}{l}\text { Day } \\
10\end{array}$ & $\begin{array}{l}\text { Day } \\
30\end{array}$ & $\begin{array}{l}\text { Day } \\
3\end{array}$ & $\begin{array}{l}\text { Day } \\
5\end{array}$ & $\begin{array}{l}\text { Day } \\
7\end{array}$ & $\begin{array}{l}\text { Day } \\
10\end{array}$ & $\begin{array}{l}\text { Day } \\
30\end{array}$ & $\begin{array}{l}\text { Day } \\
3\end{array}$ & $\begin{array}{l}\text { Day } \\
5\end{array}$ & $\begin{array}{l}\text { Day } \\
7\end{array}$ & $\begin{array}{l}\text { Day } \\
10\end{array}$ & $\begin{array}{l}\text { Day } \\
30\end{array}$ \\
\hline All & 0.001 & 0.001 & 0.001 & 0.001 & 0.001 & 0.001 & 0.001 & 0.001 & 0.001 & 10.001 & 0.001 & 0.001 & 0.001 & 0.001 & 0.001 & 0.001 & 0.001 & 0.001 & 0.001 & 10.001 \\
\hline $\begin{array}{l}\text { Talc - } \\
\text { 3\% hydrogen } \\
\text { peroxide }\end{array}$ & 0.001 & 0.001 & 0.001 & 0.001 & 0.001 & 0.001 & 0.001 & 0.001 & 0.001 & 10.001 & 0.001 & 0.001 & 0.001 & 0.001 & 0.001 & 0.001 & 0.001 & 0.001 & 0.001 & 10.001 \\
\hline $\begin{array}{l}\text { Talc- } 6 \% \text { hydroger } \\
\text { peroxide }\end{array}$ & 0.001 & 0.001 & 0.009 & 0.002 & 0.001 & 0.001 & 0.005 & 0.001 & 0.001 & 10.001 & 0.001 & 0.001 & 0.001 & 0.001 & 0.001 & 0.001 & 0.001 & 0.001 & 0.001 & 10.001 \\
\hline Talc - control & 0.001 & 0.001 & 0.001 & 0.001 & 0.001 & 0.001 & 0.001 & 0.001 & 0.001 & 10.001 & 0.001 & 0.001 & 0.001 & 0.001 & 0.001 & 0.001 & 0.001 & 0.001 & 0.001 & 10.001 \\
\hline $\begin{array}{c}3 \% \text { hydrogen } \\
\text { peroxide - } 6 \% \\
\text { hydrogen peroxide }\end{array}$ & $e^{0.001}$ & 0.001 & 0.001 & 0.001 & 0.001 & 0.001 & 0.001 & 0.001 & 0.001 & 10.001 & 0.001 & 0.001 & 0.001 & 0.001 & 0.001 & 0.001 & 0.001 & 0.001 & 0.001 & 10.001 \\
\hline $\begin{array}{c}3 \% \text { hydrogen } \\
\text { peroxide -control }\end{array}$ & 0.001 & 0.001 & 0.001 & 0.001 & 0.001 & 0.001 & 0.001 & 0.001 & 0.001 & 10.001 & 0.001 & 0.001 & 0.001 & 0.001 & 0.001 & 0.001 & 0.001 & 0.001 & 0.001 & 10.001 \\
\hline $\begin{array}{c}6 \% \text { hydrogen } \\
\text { peroxide -control }\end{array}$ & 0.001 & 0.001 & 0.001 & 0.001 & 0.001 & 0.001 & 0.001 & 0.001 & 0.001 & 10.001 & 0.001 & 0.001 & 0.001 & 0.001 & 0.001 & 0.001 & 0.001 & 0.001 & 0.001 & 10.001 \\
\hline
\end{tabular}

All comparison groups were characterized by a gradual increase in the number of lymphocytes, macrophages and histiocytes, ranging from minimum to maximum values, and by a gradual decrease in the number of neutrophils, starting with max and ending with minimum values. The predominance of neutrophilic leukocytes over other cell populations indicates an acute inflammatory reaction to the introduction of the drug; a further increase in the level of lymphocytes, macrophages, histiocytes and, accordingly, a decrease in the level of neutrophils indicates the transition of acute inflammation to chronic. By comparing the dynamics of the number of analyzed free cell elements, we found that the number of lymphocytes, macrophages and histiocytes were increasing faster. But at the same time, for the most part, their number was lower after pleurodesis with $6 \%$ hydrogen peroxide. The minimum number of neutrophils and the fastest possible reduction in all cases was observed in pleurodesis with $6 \%$ hydrogen peroxide. In the comparison group, only fluctuations in the number of the initial level of free cell elements were observed.

\section{Conclusion}

- The dynamics of the number of free cell elements in all comparison groups was estimated as stereotypical.

- The differences in all the investigated pairs were evaluated by Kruskal-Walliss criterion as significant.
- Kruskal-Walliss analysis suggests that the method of pleurodesis significantly affects the number of free cell elements involved in the inflammatory response.

- Pleurodesis with a $6 \%$ solution of hydrogen peroxide as a chemical agent significantly affects the quality of the inflammatory response, reducing its duration and severity in the organs and tissues of the rats' chests, compared with a solution of $3 \%$ hydrogen peroxide and talc.

\section{Competing Interests} interests.

The authors declare that they have no competing

\section{References}

1. Hallifax RJ, Yousuf A, Jones HE, Corcoran JP, Psallidas I, Rahman NM. Effectiveness of chemical pleurodesis in spontaneous pneumothorax recurrence prevention: a systematic review. Thorax. 2017 Dec;72(12):1121-1131. doi: 10.1136/thoraxjnl-2015-207967.

2. Izyumov MS, Bulynin VV, Bobrovskikh AM. Comparative morphological efficiency different methodics of pleurodesis by hydrogen peroxide solutions and talc. Journal of Experimental and Clinical Surgery. 2017;10(2):123-129. [Article in Russian].

3. Plaksin SA, Farshatova LI. The role of videothoracoscopy and pleurodesis in the diagnosis and treatment of inflammatory 
pleural effusions. Vestn Khir Im I I Grek. 2018;177(6):45-48. [Article in Russian].

4. Chikinev YV, Drobyazgin EA, Piontkovskaya KA, Pustovetova MG, Shcherbina KI. COMPARATIVE ASSESSMENT OF THORACOSCOPY AND DESTRUCTION OF PULMONARY BULLAS COMBINED WITH PLEURODESIS AND PLEURECTOMY. Vestn Khir Im II Grek. 2016;175(2):17-20. English, Russian. PMID: 30427141. 5. Takhtamysh MA, Efremov SI, Savinov VV, Fedorov VE, Kharitonov BS. Thoracoscopic interventions in spontaneous pneumothorax. Modern Problems of Science and Education. 2015;6:26-32. [Article in Russian].

6. Bobbio A, Dechartres A, Bouam S, Damotte D, Rabbat A, Régnard JF, Roche N, Alifano M. Epidemiology of spontaneous pneumothorax: gender-related differences. Thorax. 2015 Jul;70(7):653-8. doi: 10.1136/thoraxjnl-2014-206577.

7. Shevchenko YuL, Ablicov YuA, Vasilashko VI, Ablicov $\mathrm{AYu}$, Orlov SS, Malcev AA. Influence of the period of execution of surgical interventions for the prevention of recurrence of primary spontaneous pneumothorax on early postoperative period and long-term results. Bulletin of Pirogov National Medical \& Surgical Center. 2015;10(2):3641. [Article in Russian].

8. Hamada S, Okamoto N, Watanabe I, Tsukino M. Is pleurodesis with $50 \%$ glucose solution in patients with spontaneous pneumothorax safe?: A case series. Arch Bronconeumol. 2017 Apr;53(4):210-211. English, Spanish. doi: 10.1016/j.arbres.2016.08.018. 